\title{
THE FORESHORE ZONE DETERMINATION ACCORDING TO THE GREEK LEGISLATION, USING GEOLOGICAL AND OCEANOGRAPHIC DATA
}

\author{
Pehlivanoglou K. G. ${ }^{1}$, and Martsoukou M. ${ }^{2}$ \\ 1, 2 "The Greek Ombudsman", 5, Hatzigianni Mexi, 11528, Athens, Greece
}

\begin{abstract}
The available scientific field data of the marine and the coastal enviroment, (the wind and the wave field data, the shallow area bathymetry, the coastal area geomorphology and topography, etc.), joint to deep and shallow wave prediction numerical modelling (by means of the wind and bathymetry measurements), calculation of the nearshore wave height and maximum wave run up, were used to support the mapping of the innermost limit of the foreshore zone, according to the Greek legislation which defines that "the foreshore is the zone of land wetted by the highest however unexceptional sea wave run up" and the Supreme Administrative Court standard case law. These methods applied for two areas, which completely differ for the wind and the wave field, the geomorphologic and topographic characteristics of the coastal area, proposing different procedures for the determination of the innermost limit of the foreshore zone. The proposed limits of the foreshore zones for both areas, resulted from the study, are compared to the limits proposed by the authorised Administrative Commissions, which were published in the Official Gazette and also were applied by the local authorities for the coastal area management.
\end{abstract}

Key words: foreshore, wave height, wave run-up, coastal geomorphology.

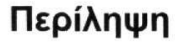

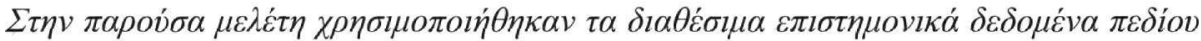

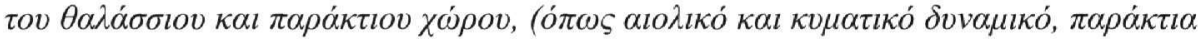

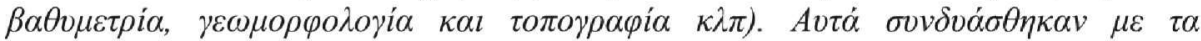

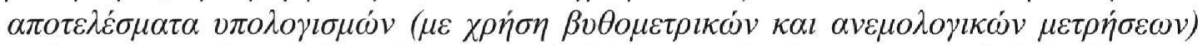

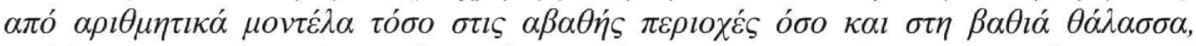

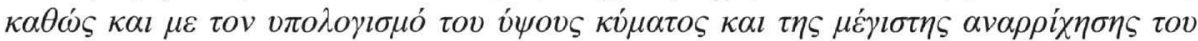

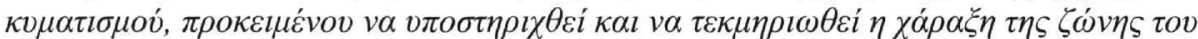

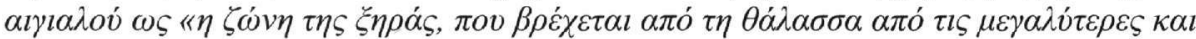

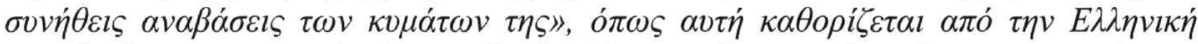

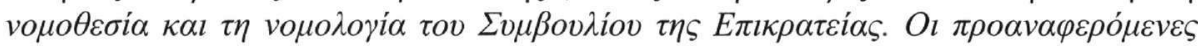

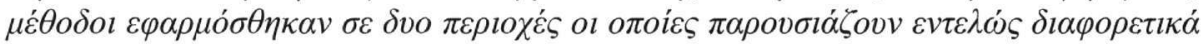

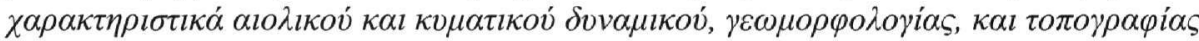

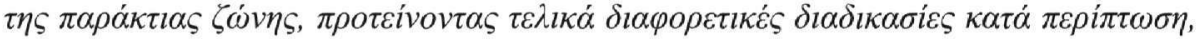

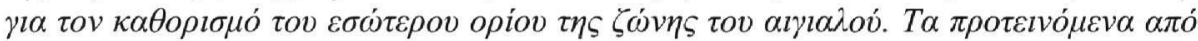

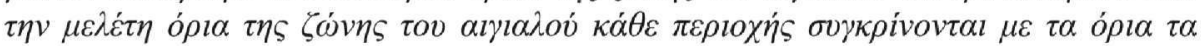




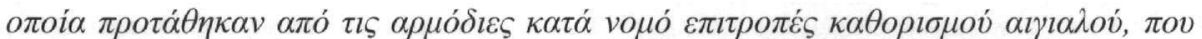

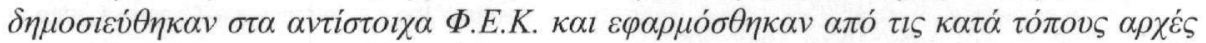

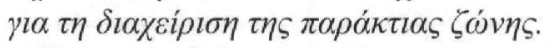

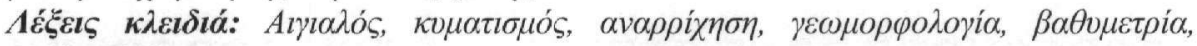

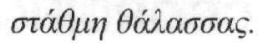

\section{Introduction - The legislative frame}

According to the current Greek legislation (Law 2971/2001, art. 1 par. 1, Official Gazette $\left.\mathrm{A}^{\prime} 285 / 2001\right)$ the modern foreshore is defined as "the zone of land wetted by the highest however unexceptional sea wave run up". Also the article 1 par. 3 specifies that the old foreshore: "...is the land zone which derived from the shifting of the foreshore towards the sea, due to illuviations or constructions and it is defined by the modern foreshore limit and the limit of the older foreshore". Articles 3, 4, 5, 6, and 9 of the aforementioned law regulate the procedure and mention some of the environmental criteria and scientific data for the definition of the modern and the old foreshore. Furthermore the 1089532/8205/B0010 (Official Gazette B'595/2005) Joint Decision of the Ministers of Finance and of Environment, Physical Planning and Public Works specifies the criteria that the local authorized Commissions takes into consideration after inspection, before delimiting the modern foreshore and/or the old foreshore zone, (the coastal geomorphology and structure, the wave and wind field, the vegetation, the relief, the slopes, the bathymetry, etc.).

Thus, the Greek legislator establishes an administrative procedure for the binding definition of the foreshore delimitation line as an environmental phenomenon, and more specifically as the highest but not unexceptional sea wave run up, to a specific land zone (Supreme Administrative Court 1185/1996, 3778/2004, 2975/2004).

It is evident that the aforementioned legislative framework includes environmental and other criteria without defining the scientific methodology that the Commission is bound to use for the evaluation of aforementioned environmental data, but it is not held by law to use specific scientific and technical methods before reaching decision. It is important to highlight that the legislator excludes the oral testimonies from the proceedings of determining the old foreshore zone (art. 5 par. 3 of Law 2971/2001), in order to introduce more objective criteria of definition. Therefore, the Administration, whenever deciding on the foreshore, merely attests the existing state of facts as to the area between mean low water and mean high water in order to proceed to a substantiated delimitation.

In France, article 26 of Law 86-2 of January the $3^{\text {rd }} 1986$ on Management, Protection and Optimal Use of the coastline states that "the foreshore limits are ascertained by the State upon inspection or use of information drawn from scientific studies". The above article is further specified by the 2004-309 Decree of March $29^{\text {th }}$ 2004, which stipulates as information provided by scientific studies "especially the topographic, meteorological, tidal, wave field data, as well as sedimentologic, botanic, zoological or historical data".

It is necessary to stress that the European Union Law, in other but similar cases where natural phenomena are involved, equally considers the use of scientific data important, e.g. the EC/92/43 Directive of May the $21^{\text {st }} 1992$ on "Conservation of Natural Habitats", which has been transferred into Greek law by the Ministerial Decision 28/1998. Article 5 states that the Commission will decide "on the basis of relevant and reliable scientific information" and if there is no unanimity it will be decided "on the basis of scientific data provided by both parties."

The Supreme Administrative Court standard case law defines as well that; the foreshore determination by the Commission should be based on scientific experience and criteria derived from scientific studies (case number 1185/1996, 3778/2004, 2975/2004, 3941/2000, 2954/1998), geomorphologic, geologic - sedimentologic data (case number 1178/1994, 1508/2003), geological studies (case number 751/2000, 3143/1992) and should be based on inspection at the right time. 
Thus, expert opinions on the matter should be ordered by the Court, for the completion of the case file with scientific data (case number $751 / 2000,1508 / 2003,1178 / 1994$ ), especially when the Commissions are unable to form a scientifically valid judgment regarding the wind and wave data in relation with the geological or geomorphologic data of a specific coast.

Two characteristic case studies presented in this paper, derived from the Greek Ombudsman archive, which received a considerable number of citizen reports and queries on the proceedings and criteria used by the Administration's Commissions for defining the seashore. These case studies indicate the essential contribution of the dedicated scientific studies, for the determination of the modern and the old foreshore

\section{Methods}

The wave height very close to the coastline as well as the maximum wave run up on the coastal area, are the critical oceanographic parameters, which combined with geomorphologic and topographic data, can outline and determine the innermost limit of the modern or old foreshore zone, that can be affected by the sea.

In application to the aforementioned legislation, the available scientific field and archive data of the marine and the coastal enviroment, (wind and wave field data, shallow area bathymetry, coastal area geology, geomorphology, stratigraphy and topography), together with wave height prediction numerical modelling (Holthuijsen et al. 1999, C.E.R.C. 1984), and maximum wave run up (Mase 1989), were used to support the definition of the modern foreshore zone in Ag. Marina Attiki area, Vromolimno area - Skiathos Island (Fig. 1).

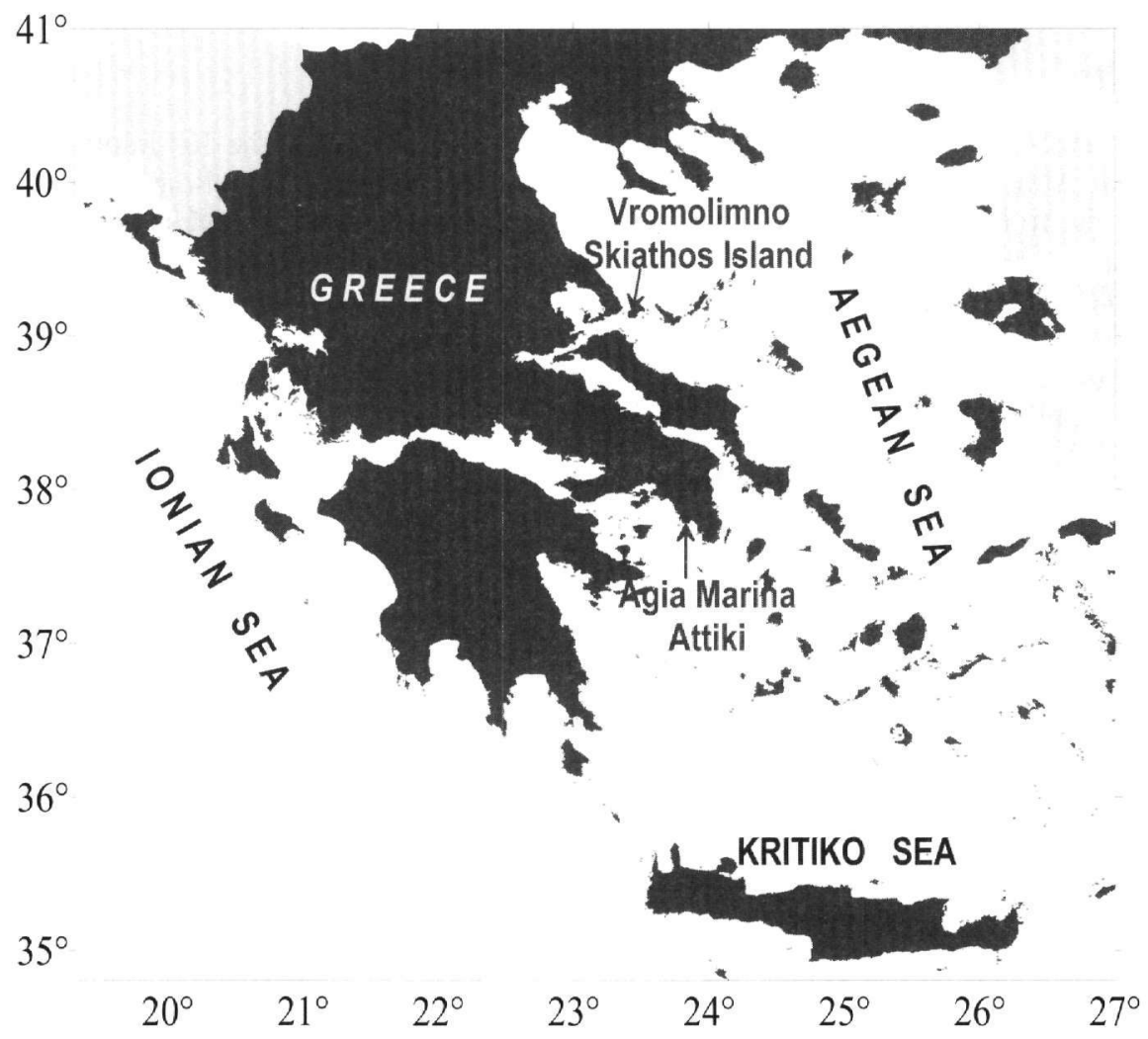

Figure 1 - Map of the study areas: Agia Marina Saronikos Gulf, Attiki district and Vromolimno Skiathos Island 
The procedure of the determination of the wave height and the wave's run up has been applied in two Greek coastal areas, which differ in their geomorphology, oceanography and meteorology. The proposed procedure includes: a) Oceanographic field data collection such, as wind speed and direction statistical data derived from the Hellenic National Meteorological Service measurements' network, wave height and wave period derived from the Hellenic Centre for Marine Research observation buoys, sea level measurements from the permanent tide gauges network of the Hellenic Navy Hydrographic Service, b) Topographic and bathymetric archive and field data, collected from the available hydrographic and bathymetric charts and field measurements, in order to reproduce the relief of the shallow underwater and the coastal area, c) Sequential aerial photographs, d) Geology and geomorphology data of the coastal and shallow underwater area (the composition and the grain size distribution of the sediments), e) Wave height and wave period prediction for the deep sea area. If no available field measurements exist, the C.E.R.C. (1984) wave prediction model, is being applied and $f$ ) The maximum wave run up prediction $\left(R_{\max }\right.$ according to Mase 1989), based on the wave height and the coastal area characteristics. The above, added to the sea level rise due to the tide, was used for the calculation of the maximum level of the coast, that will be affected by the waves under extreme weather conditions.

The following assumptions were made, in order to apply the requirement of the legislation, related to the modern foreshore zone determination ${ }^{1}:$ 1) the maximum considered wind speed and direction as well as the wave height and period produced, affect the coastal area at least annually, 2) the maximum irregular waves' run up on the coast, is calculated from the previous mentioned data. The wave characteristics, such as wave height, wave period, coast coefficient, as well as the maximum wave run up on the coast was estimated according to C.E.R.C. (1984) and Mase (1989) respectively.

\section{Results}

The coastal areas studied were: Agia Marina Saronikos Gulf, located at the $36^{\text {th }}$ kilometer of the SSW coast of Attiki district, E-SE coast of Saronikos Gulf, and the Vromolimno area, located 10 kilometers far from Skiathos town, at the S-SW coast of Skiathos Island, (Figs 1, 2, 6). The selected areas are both S-SW oriented, but they are completely different for their physical, geomorphologic and oceanographic settings. The first one, Agia Marina, characterized by a narrow, steep, rocky coast, sharp sea bottom relief and very extensive fetch. The second area, Vromolimno Skiathos Island, characterized by a wide, sandy, smooth coastal zone, a smooth sea bottom relief and limited fetch.

\subsection{Agia Marina, Attiki - Saronikos gulf}

Agia Marina coastal area studied belongs to the E-SE coast of Saronikos Gulf, between the kilometric locations $35.5 \mathrm{Km}$ and $36.5 \mathrm{Km}$ of the Athens - Sounion Avenue (Fig. 2). The area is S-SW oriented and protected from the N, NW, WNW, NE, ENE and E winds. The effective fetch to the W and WSW direction varies from 1n.m. to 30 n.m., while to the S, SE and SW direction the fetch varies from 5 n.m., 120 n.m. to 200 n.m respectively.

The foreshore zone of the area which was determined by the decree No. 13/1963 «For the establishment of the beach from Vouliagmeni to Lavrion area» (Official Gazette of the Hellenic Republic, 6 B'/15-01-1963) reach at the level $+9.6 \mathrm{~m}$ up to $+12 \mathrm{~m}$ along the coast. Consequently the authorized committee, which determined the modern foreshore limit, accepted that the maximum sea level rise that affects the coast, due to the maximum wave run up and the tide as well extends up to $+9.6 \mathrm{~m}$ to $+12 \mathrm{~m}$.

\footnotetext{
Defined according to the Law 2971/2001 as "the zone wetted by the bigger however unexceptional sea wave run up"
} 


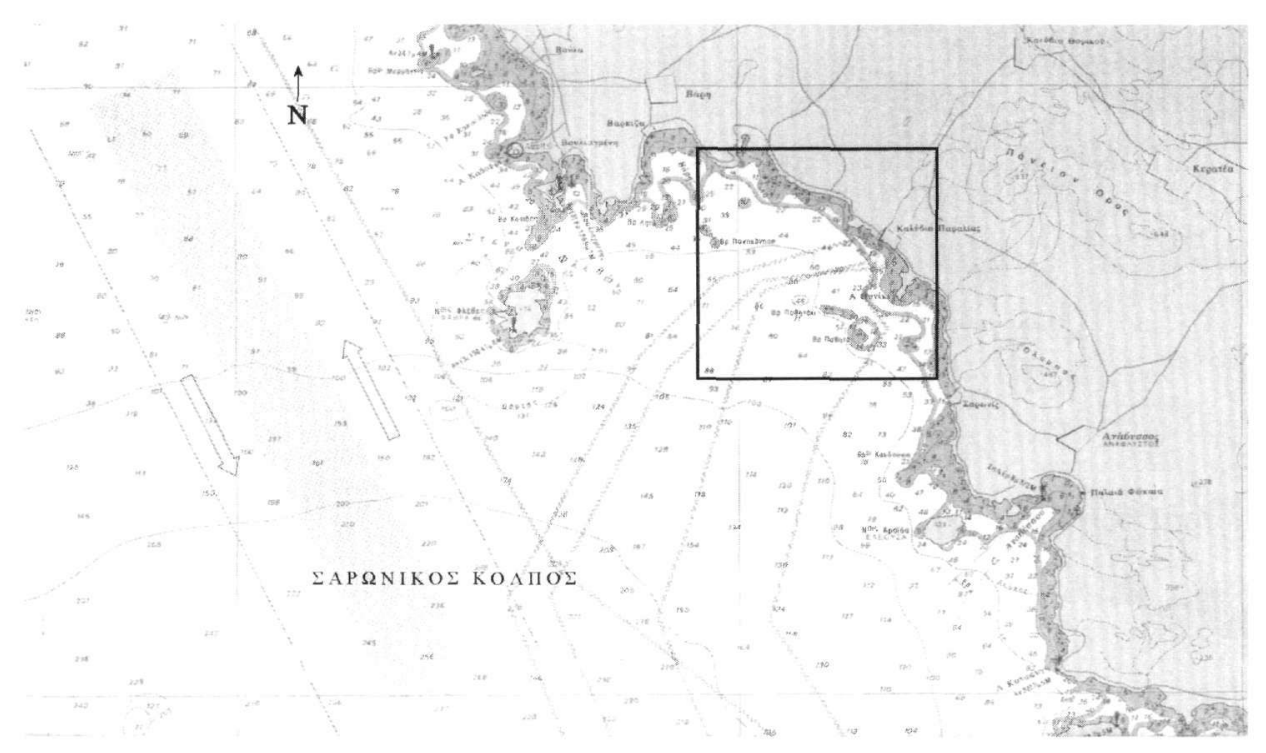

Figure 2 - Study area: Agia Marina Saronikos Gulf, Attiki district (Nautical chart 413, H.N.H.S)

\subsubsection{Geomorhology}

The coast presents sharp relief, intense slopes varying between $20^{\circ}$ and $30^{\circ}$ and narrow rocky beach zone, 8 to $17 \mathrm{~m}$. wide, partially formatted by human intervention. The intense sea bottom slope as well, varies between $7^{\circ}$ and $10^{\circ}$. Along the coastal zone, landward of the narrow rocky beach zone, the $4 \mathrm{~m}$ height conglomerate rock eroded from the wave action (Figs 3,4).

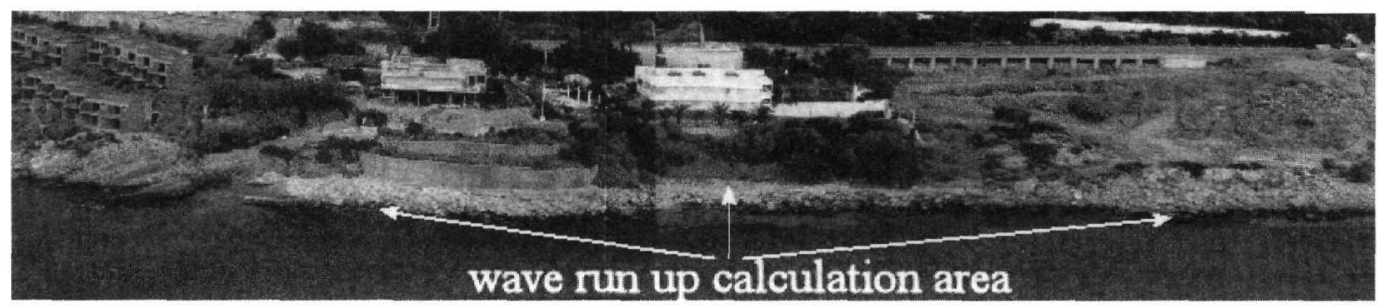

Figure 3 - Geomorphology of Agia Marina, Saronikos Gulf study area, as well as the wave run-up calculation area

A narrow, coherent, coarse-grained, sandy layer, $30-40 \mathrm{~cm}$ thick, crosses the conglomerate $20^{\circ}$ towards N-NW direction. A sandy-pebble layer without signs of marine erosion lies over the conglomerate, followed by schist. The sporadic, permanent, self-sown vegetation level begins from the lower limit of the schist, at $+3.6 \mathrm{~m}$ to $+4 \mathrm{~m}$ (Fig. 4).

\subsubsection{Wave height calculation}

The extreme conditions ${ }^{2}$, which were considered, that prevail in Saronikos gulf area are caused by the 8 Beaufort S, SE or SW winds. These conditions present at least $0.011 \%$ annually, according to the Hellenic National Meteorological Service statistic data sheet, "Athens Hellinikon" airport meteorological station (Table 1).

\footnotetext{
${ }^{2}$ the very strong or stormy wind conditions which are observed at least annually
} 


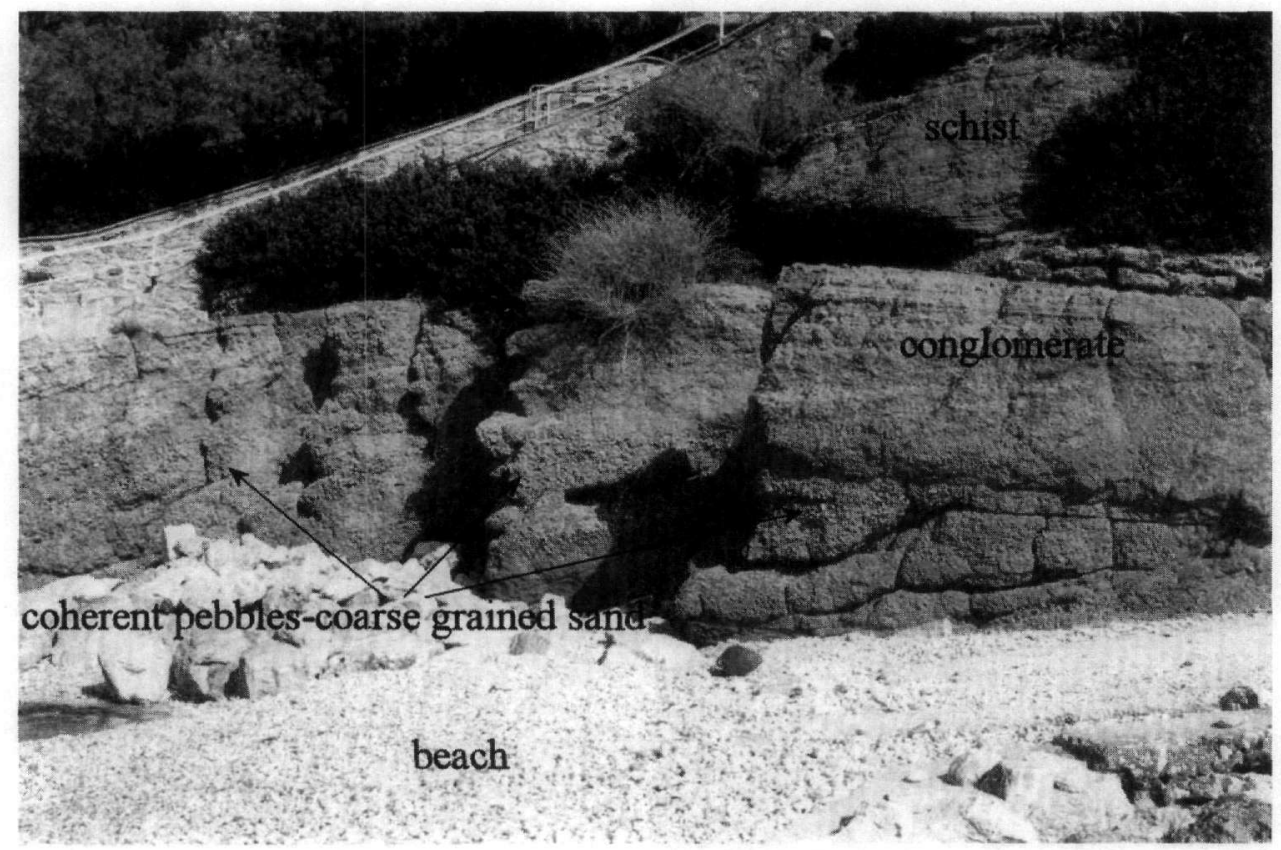

Figure 4 - Detailed geology and geomorphology of the Agia Marina coastal area

The wave height which expected to be observed at the deeper sea area, 250-500 $\mathrm{m}$ far from the coast, under the action of the 8 Beaufort very strong or stormy SW winds, is $4.1 \mathrm{~m}$, according to the data of the table 1. Lower wave height, $2.3-3.6 \mathrm{~m}$, expected to be observed for the other directions (SE, S or W), as well as in the shallower area, due to the sea bottom relief effect, the reflections, the attenuation etc.

Table 1 Wind force, direction frequency $\%$ and the corresponding wave height $(\mathrm{m})$ * (“Athens Hellinikon" airport meteorological station, time period 1955-1987)

\begin{tabular}{|c|c|c|c|c|c|c|c|c|}
\hline & \multicolumn{4}{|c|}{ Direction frequency \% } & \multicolumn{4}{c|}{ Wave height } \\
\hline Wind force (Beaufort) & SE & S & SW & W & SE & S & SW & W \\
\hline $\mathbf{6}$ & 0.055 & 0.131 & 0.066 & 0.077 & 1.7 & 2.3 & 2.6 & 1.4 \\
\hline $\mathbf{7}$ & 0.011 & 0.022 & 0.011 & 0.011 & 2.2 & 2.9 & 3.3 & 1.8 \\
\hline $\mathbf{8}$ & 0.000 & 0.011 & 0.011 & 0.000 & 2.8 & 3.6 & 4.1 & 2.3 \\
\hline
\end{tabular}

* The directions and the extreme wind force conditions that affect the study area are mentioned

Long term (October 1998 to October 1999) wave height, wave period, wind speed and direction measurements, of the Hellenic Centre Marine Research "POSEIDON" project observation buoy, were used to verify the accuracy of the previous mentioned wave height predictions. The boy was moored northern of the study area at the position $37^{\circ} 53^{\prime} 18.8^{\prime \prime} \mathrm{N}, 23^{\circ} 41^{\prime} 19.9^{\prime \prime}$ E. The mooring boy and the adjacent area presents identical morphologic and oceanographic characteristics to the study area, such as effective fetch, bathymetry and wind field (Fig. 5).

These measurements, which were confirmed during the extreme weather conditions which prevailed during the November $22^{\text {nd }}$ and $23^{\text {rd }}, 1999$, present that: A) the significant wave height in the area during October 1998 and October 1999 didn't exceed $2.1 \mathrm{~m}, \mathrm{~B}$ ) the maximum wind speed was $17.5 \mathrm{~m} / \mathrm{sec}$ ( 8 Beaufort) as well as the corresponding wind direction $170^{\circ}$ (S wind), C) the maximum wave height during this period did not exceed $3.7 \mathrm{~m}$, and D) the wave period was $4.5 \mathrm{~s}$. 


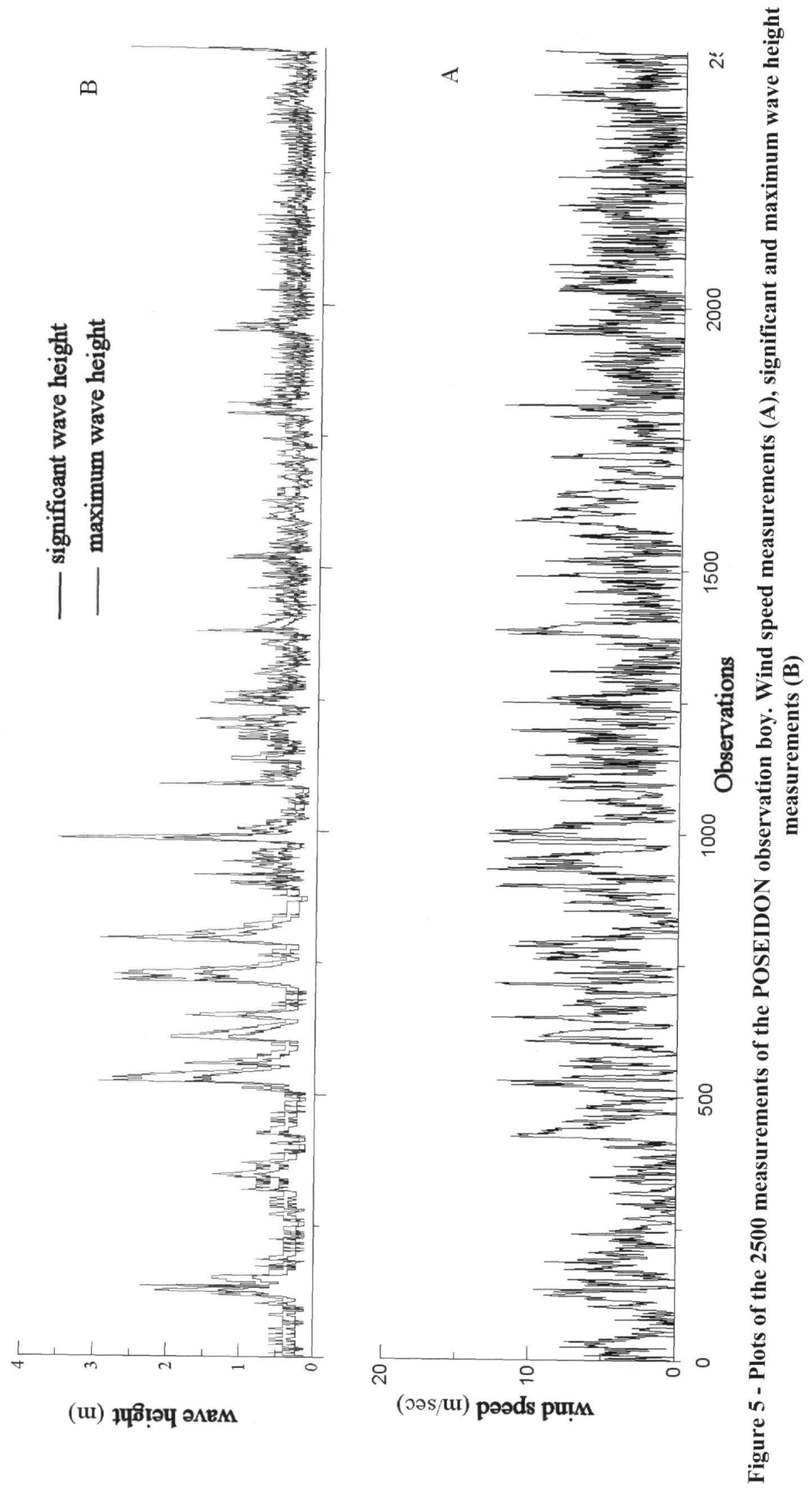


The deep-sea maximum wave height calculated by the C.E.R.C. (1984) wave prediction model, coincides with the maximum wave height measured by the observation buoy. Furthermore the maximum wave run up on the coast that was calculated, according to Mase (1989) prediction model, did not exceed $+3.5 \mathrm{~m}$, assuming that the maximum wave height was $3.7 \mathrm{~m}$, the wave period was $4.5 \mathrm{~s}$ and the mean slope was $10^{\circ}$ (mean slope of the shallower sea bottom up to the coast area). Assuming that the sea level rise due the tide does not exceed $3 \mathrm{~cm}$ (mean high water level - mean sea level), according to the Piraeus tide gauge, the uppermost sea level that affects the coast does not exceed $+3.6 \mathrm{~m}$.

Consequently, the upper limit of the modern foreshore zone should be the $+3.6 \mathrm{~m}$ level according to the available data and the Law 2971/2001.

\subsection{Vromolimno - Skiathos Island}

The second area is located at the inner part of Platanias bay, at the southern part of Skiathos Island, oriented towards S-SSW direction (Figs 1, 6). The effective fetch towards W, SW, WSW and SSE directions was calculated to 18 n.m., 10 n.m., 35 n.m., and 32 n.m. respectively. This area is very well protected from the N, NW, WNW, NE, ENE and E winds due to the short hills (30 m to $84 \mathrm{~m}$ height) which surround the Platanias bay.

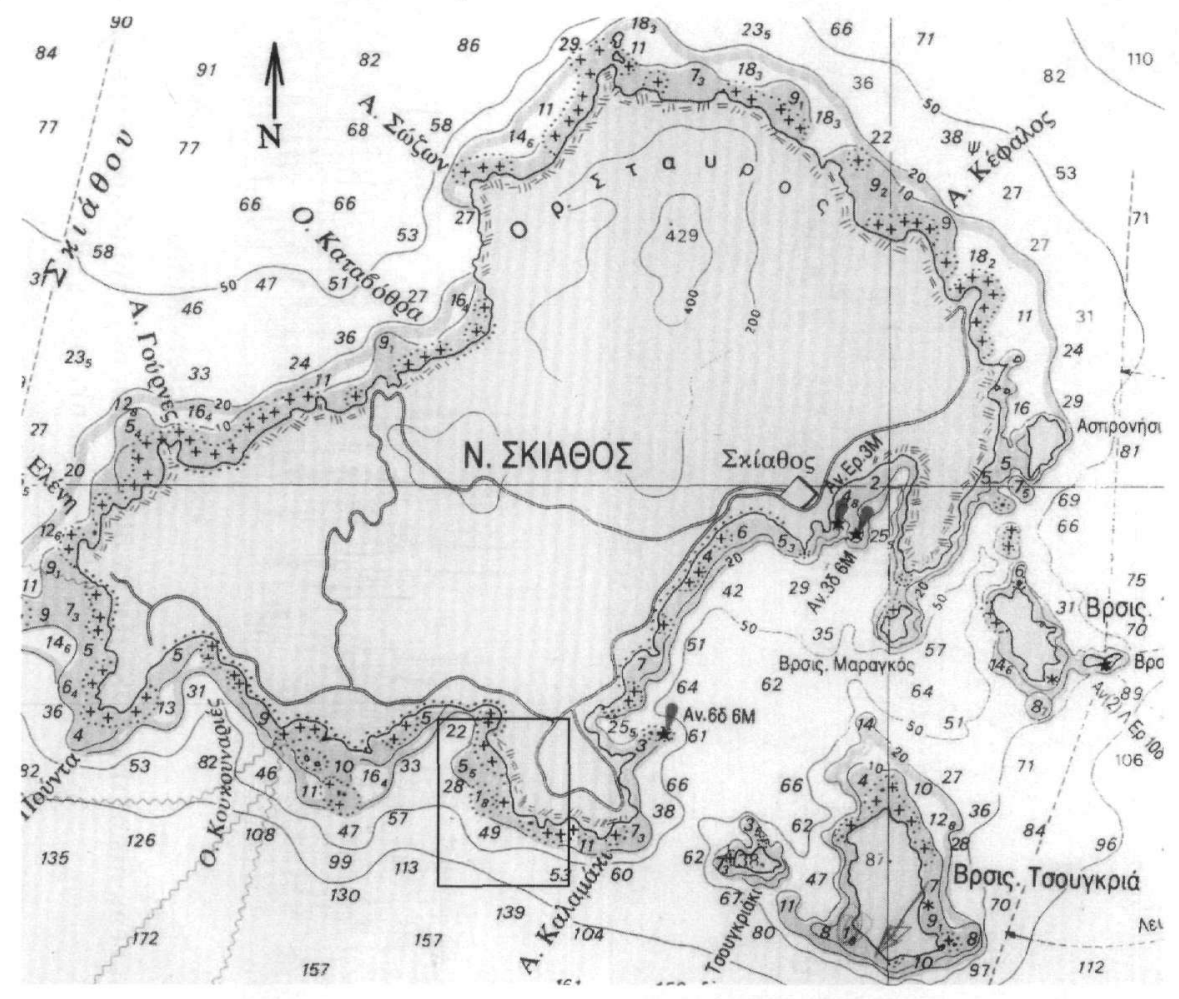

Figure 6 - Map of the study area: Vromolimno, Skiathos Island (Nautical chart 312, HNHS)

The act No. 155/14-11-1990 (Official Gazette of the Hellenic Republic, issue 670 D'/30-11-1990) "Determination of the limits of the modern foreshore zone and the beach at Vromolimno area Skiathos Island Prefecture of Magnesia", of the Prefect of Magnesia and the topographic diagram attached, defines the modern foreshore zone of the study area. The innermost limit has been determined approximately to the level $+1.0 \mathrm{~m}$ along the coast. Consequently, the authorized committee, which determined the modern foreshore limit, had accepted that the maximum sea level rise that affects the coast, due to the maximum wave run up and the tide as well, extends up to $1.0 \mathrm{~m}$. 


\subsubsection{Geomorphology}

Gneiss schists surround the coastal area (Ferentinos 1972). Along the coastal zone, an elongated $2 \mathrm{~m}$ height dune has been developed parallel to the coastline (Figs 7, 8). Landwards, in the outer periphery of the dune there exists a $14000 \mathrm{~m}^{2}$ size small elongated brackish lake, known as "Vromolimno Lake". The lake was in contact with the sea, supplied with fresh salt seawater via two channels at the ands of the lake, the north and the south channel.

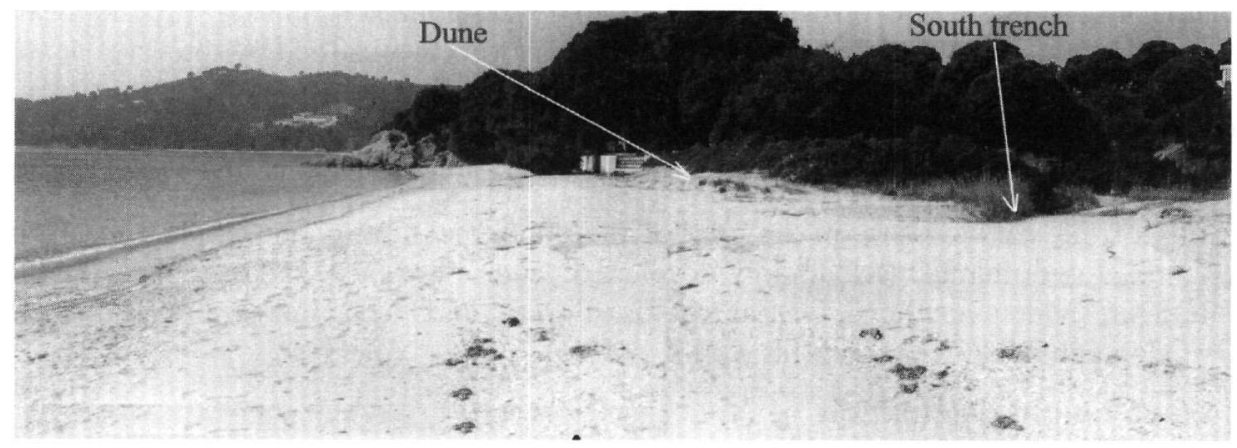

Figure 7 - Geomorphology of Vromolimno area, Skiathos Island. Northern part of the of the smooth sandy beach and the dune with self-sown dendroid or bushy vegetation

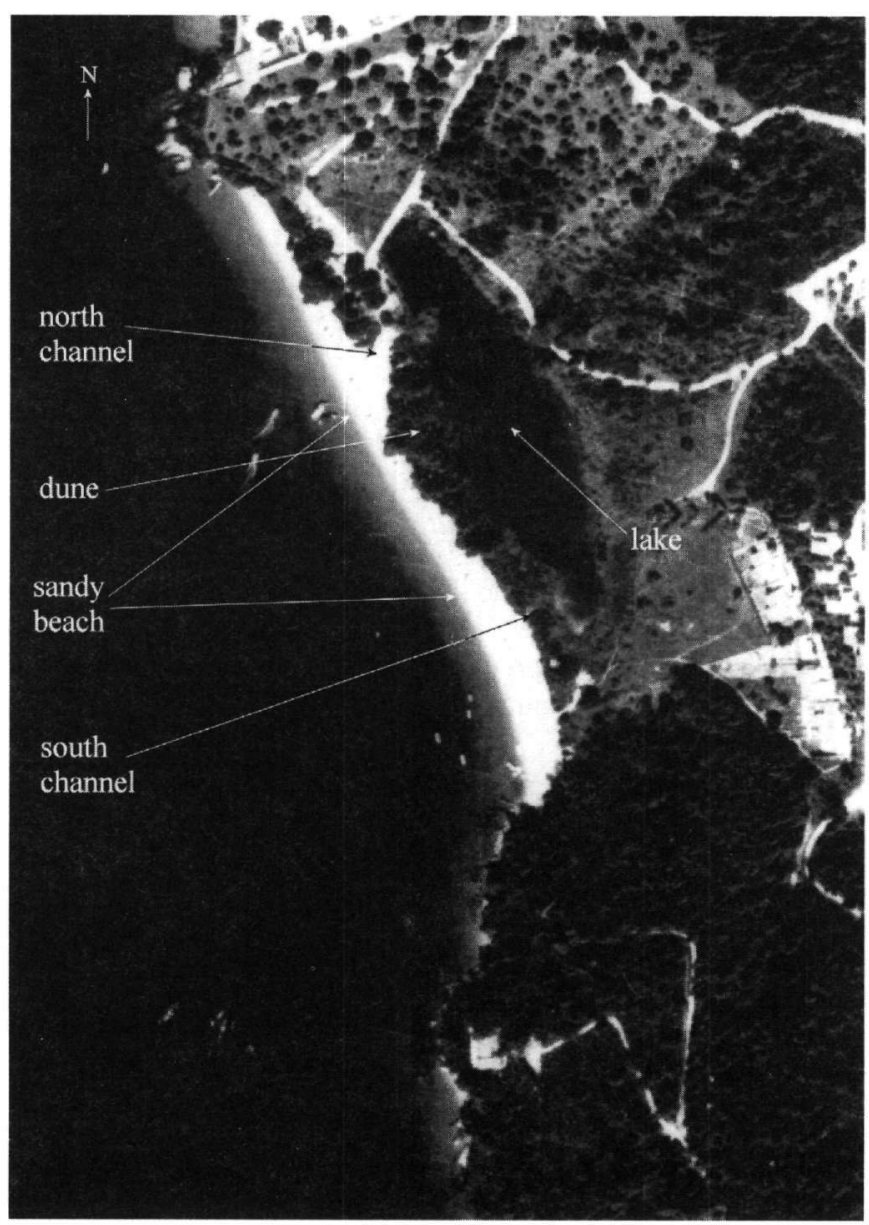

Figure 8 - Extract of the aerial photograph of Vromolimno, Skiathos Island (HMGS 1988) 
The dune, the lake as well as the north and the south contact channels, were recognised on Hellenic Military Geographic Service aerial photos, of the years 1945, 1956, 1960, 1980 and 1988. The lake, up to the last decade was in contact with the sea through these sandy channels, 0.6 to $1 \mathrm{~m}$ wide (Fig. 7).

The sea bottom slope along the shallower coastal area varies from $0.8^{\circ}$ to $1^{\circ}$, while sea bottom rises exists far from the coastline. The slope of the beach area varies from $1^{\circ}$ northwards to $1.5^{\circ}$ southwards. The sandy beach consists of medium to coarse-grained sand (Fig. 7). The mean grain diameter varies from 0.25 to $0.75 \mathrm{~mm}$ and the grains are very well sorted by the wave action. The previous mentioned sandy material contains shell and skeletal fragments of marine foraminifera (Pehlivanoglou and Karamitrou 2003). These data indicate the marine influence on the sandy material, the accumulation and the sorting according to the grain size due to the waves' action.

Landwards of the sandy beach, in the area of the dune, medium to fine grained sand prevails, partially mixed with humus. Remarkably developed dendroid or bushy vegetation is observed on the dune area, evident in the terrestrial photos (Fig. 7) and the aerial photos of the Hellenic Military Geographic Service (Fig. 8) as well.

\subsubsection{Wave height calculation}

Wind speed and direction data from the Skopelos' Island meteorological station, the nearest to the Skiathos Island meteorological station of the Hellenic National Meteorological Service network were used, in order to estimate the extreme conditions, which prevail at least once annually in the Vromolimno area. The measurements period was from 1956 to 1996.

Table 2 Wind force frequency \% versus wind direction (Skopelos, 1955-1996)*

\begin{tabular}{|c|c|c|c|c|c|}
\hline & Wind speed & \multicolumn{4}{|c|}{ Frequency \% of the wind force } \\
\hline Wind force (Beauf). & $(\mathrm{m} / \mathrm{sec})$ & SE & S & W & SW \\
\hline 7 & $13,9-17,1$ & 0,056 & 0,133 & 0,055 & 0,033 \\
\hline 8 & $17,2-20,7$ & 0,011 & 0,033 & 0,033 & 0,033 \\
\hline 9 & $20,8-24,4$ & 0,00 & 0,00 & 0,022 & 0,022 \\
\hline 10 & $24,5-28,4$ & 0,00 & 0,00 & 0,011 & 0,011 \\
\hline
\end{tabular}

*Only the extreme conditions and the wind directions that affect the area are mentioned

The 8 Beaufort S, W and SW winds present remarkable annual frequency $(0.066 \%)$, according to the previous mentioned observations (Table 2). These conditions have been suggested that fulfill the Law 2971/2001 requirements "the bigger however unexceptional sea wave run up". The 9 or 10 Beaufort winds present a very low annual frequency, so it was assumed that they do not fulfill the legislation requirements (Table 2).

The most extensive effective fetch, 35 n.m., was observed towards the WSW direction, thus was suggested as the most convenient input for the wave height calculation. Assuming that, A) 8 Beaufort $(20 \mathrm{~m} / \mathrm{sec})$ wind blows at least $4.5 \mathrm{~h}, \mathrm{~B})$ the effective fetch does not exceed $35 \mathrm{n} . \mathrm{m}$., and C) the wave period is $7.2 \mathrm{~s}$, then the maximum wave height calculated according to C.E.R.C. (1984) wave prediction model would be $3.3 \mathrm{~m}$ in the deep sea area.

Suggesting that the mean slope of the shallow sea bottom and the coastal area is $1^{\circ}$, the coefficient of the coast was calculated $\left(\xi_{0}=0.08257\right)$ as well as the maximum wave run up on the coast $\mathrm{R}_{\max }=$ $+1.20 \mathrm{~m}$, according to Mase (1989).

According to Skopelos' tide gauge's continuous records, from 1999 up to date, the mean sea level rise due to the tide (mean high water level - mean sea level) was estimated to $+0.14 \mathrm{~m}$ (HNHS 2006). 
Therefore the uppermost sea level that affects the coast does not exceed $+1.34 \mathrm{~m}$, including the sea level rise due to the maximum wave run up and the tide as well.

Consequently, the upper limit of the modern foreshore zone of Vromolimno area, Skiathos Island, should be the $+1.34 \mathrm{~m}$ level according to the available data and the Law 2971/2001.

\section{Conclusions}

The suggestion which is mentioned in the official gazette of the Hellenic Republic, issue 6 B' (1501-1963), that the level of the modern foreshore of the Agia Marina Saronikos Gulf area, which was determined by the authorized committee, between the kilometric locations $35.5 \mathrm{Km}$ and 36.5 $\mathrm{Km}$ of Athens - Sounion avenue, comes up to the level $+9.6 \mathrm{~m}$ and/or to $+12 \mathrm{~m}$ on the coastal area, can't be confirmed from the available field and laboratory geomorphologic, bathymetric, meteorological, and tidal measured data as well as by the wave measured and predicted data.

On the contrary, according to the field measurements and the laboratory wave height predictions, the maximum wave height as well as the sea level rise on the coastal area due to the wave run up and the tide, that affects the coast doesn't exceed $+3.6 \mathrm{~m}$. Consequently, the innermost limit of the modern foreshore zone which is estimated by the present study according to the law 2971/2001, as "the zone wetted by the bigger however unexceptional sea wave run up", is much lower than the level estimated by the authorized committee, mentioned in the previous paragraph and therefore should be determined at the $+3.6 \mathrm{~m}$ level according to the available data and the Law 2971/2001.

Also the suggestion which is mentioned in the official gazette of the Hellenic Republic, issue 670 D' (30-11-1990), act No. 155/14-11-1990 "Determination of the limits of the modern foreshore zone and the beach at the Vromolimno area Skiathos Island Prefecture of Magnesia", that the modern foreshore, determined by the authorized committee, reaches up to the level $+1.0 \mathrm{~m}$, can't be confirmed from the available field and laboratory geomorphologic, bathymetric, meteorological, and tidal measured data as well as from the wave measured and predicted data.

According to: a) the laboratory wave height predictions, b) the maximum wave height and c) the cumulative sea level rise on the coastal area due to the wave run up and the tide that affects the coast, has been calculated that comes up to $+1.34 \mathrm{~m}$ level.

Therefore, the innermost limit of the modern foreshore zone, which is estimated by the present study according to the law 2971/2001, is higher than the level determined by the authorized committee, mentioned in the previous paragraph and therefore should be determined at the +1.34 m level according to the available data and the Law 2971/2001.

The previous mentioned characteristic cases of the modern foreshore determination, indicate the essential contribution of the scientific dedicated studies, for the estimation of the uppermost limit of the sea level rise that affects the coastal area. Both cases indicate the incorrect estimation (either over-estimation or under-estimation) by the authorised committees, of the maximum sea level rise on the coastal zone.

\section{Acknowledgments}

The authors wishes to acknowledge Dr Nikiforos Kypraios, Coastal Engineer, for his comments and corrections.

\section{References}

Coastal Engineering Research Center (CERC), Department of the Army, 1984. Shore Protection Manual, vol. I, Washington D.C.

H.N.M.S. (Hellenic National Meteorological Service), 1997. Statistic Data, "Athens Hellinikon" airport meteorological station. 
H.N.M.S. (Hellenic National Meteorological Service), 1997. Statistic Data Skopelos meteorological station.

H.N.H.S. (Hellenic Navy Hydrographic Service), 1991. Wave Tide Data for Hellenic Ports. $4^{\text {th }}$ Edit. Athens, 73pp.

H.N.H.S. (Hellenic Navy Hydrographic Service 2004. C. Platamon to Skyros I., Chart No. 312. Scale 1:150000

H.N.H.S. (Hellenic Navy Hydrographic Service 1997. Saronikos Gulf., Chart No. 413. Scale 1:100000

Mase, H., 1989. Random Wave Run up Height on Gentle Slopes. Journal of the Waterway, Port, Coastal and Ocean Engineering Division, American Society Civil Engineers (ASCE), $115(5), 649-461$.

Pehlivanoglou, K., and Karamitrou, Z., 2003. Anthropogenic effects on the geomorphology of the Vromolimno area, Skiathos Island, $7^{\circ}$ Panhell. Symp. Ocean. \& Fish., 186pp, Crete, Greece. (in Greek - English abstract)

Ferentinos, G.C., 1972. The geology - petrology of the island of Skiathos, PhD thesis, Univ. Patras. (in Greek - English abstract) 